\title{
Editorial
}

Tomasz Napierała*, Kemal Birdir

\section{Competition in Hotel Industry: Theory, Evidence and Business Practice}

https://doi.org/10.2478/ejthr-2020-0017

\section{Understanding of competition}

A critique of neoclassical (neoliberal) understanding of the phenomenon of competition was enabled in the $20^{\text {th }}$ century by numerous new economic, but also managerial, geographical and sociological theories that defined and interpreted the phenomenon of competition in a brand new manner (Hunt, 2000; Rumelt, 1997). Rejecting the assumptions of the neoliberal theory (particularly its claims of market equilibrium and access to market information) had a significant impact on redefining the theory and methods of investigation in various contexts of competition: economic, managerial, spatial, relational and institutional. Interestingly, the results diagnosed by empirical non-economic research, mainly geographical, but also observations of business practices impacted the development of economics (Boschma \& Frenken, 2006). The goal of this special issue of European Journal of Tourism, Hospitality and Recreation is to discuss the theoretical concepts, study the empirical evidence and business practice contributions to better understand the recent notion of competition in the hotel industry.

\section{Competition in the hotel industry}

The focus of recent interdisciplinary studies on competition in the hotel industry covers different research problems. Regarding the resource (Penrose, 2011) and

\footnotetext{
*Corresponding author: Tomasz Napierata,University of Lodz, Faculty of Geographical Sciences, Poland, 90-142 Lodz, Kopcinskiego 31 CiTUR, Centre of Tourism Research, Development, and Innovation, Portugal, 2520-614 Peniche, Rua do Conhecimento No 4, ORCID: 0000-0002-6407-5197, Email: tomasz.napierala@geo.uni.lodz.pl Kemal Birdir, Mersin University, Faculty of Tourism, Turkey, 33110 Yenişehir/Mersin, Çiftlikköy, ORCID: 0000-0003-1353-3618, Email: kemalbirdir@mersin.edu.tr
}

resource-advantage (Hunt, 2000) theories, discussion on key resources for achieving competitive advantage by hotels and hotel chains seems to be crucial. The following resources should be emphasised in the lodging industry: knowledge confronted with innovation and collaboration ability (Hjalager, 2010; Napierala \& Szutowski, 2019), social and institutional relations and networks confronted with the concept of coopetition (Czernek \& Czakon, 2016), quality of environment confronted with the goals of sustainable development (Balli, Sigeze, Manga, Sahilli Birdir, \& Birdir, 2018). Considering the abovementioned resources, the impacts of social media on competitiveness in the hotel industry need to be discussed. This results from the linkage between modern resources of knowledge, technology and recent changes of social and institutional relations (Buhalis \& Licata, 2002).

On the other hand, the contribution of the evolutionary theory (Schumpeter, 1939) needs to be emphasised, as it enabled us to better understand competition as a process, and not as a state. Particularly, the evolutionary approach allowed for an explanation of spatial processes of competition in the hotel industry, mainly location selection (Dökmeci \& Balta, 1999), or the understanding of factors influencing survival and development of hotel enterprises (Brouder \& Eriksson, 2012).

\section{Contribution: between innovation and sustainability}

Regarding the contribution to this special issue, the core of competition in the hotel industry is identified on an axis extending between innovation and sustainability. Oxenswärdh (2020) argues that sustainability applied to the hotel industry might increase the competitive advantage of the enterprises focused on guests aware of sustainability issues. However, a shift from professional accountability towards more human responsibility is demanded. Sustainability must be considered by hoteliers not as a marketable slogan but a core value enabling the development of their enterprise and its stakeholders. Ulucan 
(2020) considers location as a crucial resource from the perspective of hotel competitiveness. She confirms that economic factors and agglomeration effects are the main important determinants of previous hotel location decisions. However, from the perspective of achieving sustainable development goals, benefits of localities and regions should be considered simultaneously in the process of hotel location selection.

On the other hand, Parzych \& Brkić-Vejmelka (2020) indicate that a hotel location has moderate impact on the overall assessment of the hotel by guests. Instead, innovative technologies (Giousmpasoglou \& Thuy Hua, 2020; Napierała, Bahar, Leśniewska-Napierała, \& Topsakal, 2020), modern facilities and amenities (Bik, Poreda, \& Matczak, 2020; Parzych \& Brkić-Vejmelka, 2020) and sustainable approach (Oxenswärdh, 2020) increase attractiveness of a hotel's offer from the perspective of potential guests and, in consequence, make competitive advantage achievable.

Giousmpasoglou \& Thuy Hua (2020) argue that innovative technologies might significantly increase employees' willingness, efforts and resources to better perform tasks that require more attention and to stimulate the improvement employee skills and competencies at the same time. The goal of introducing innovative technologies in the hotel industry should not be to reduce employment but to increase the performance of employees (Napierała, Bahar, et al., 2020). This is particularly important in the case of typical housekeeping department work, often negatively influencing physical and emotional health of employees (Dwomoh \& Moses, 2020). It must be stressed that the relationship between the hotel industry and its employees is a significant context of sustainability. Thus, innovative technologies can make the industry more sustainable, not only from the perspective of energy savings, waste and water management, but also from the perspective of employees' personal development.

\section{The future of competition in the hotel industry}

The current COVID-19 pandemic significantly influences the hotel industry, mainly enterprises operating in urban, internationalised, and meetings, incentives, conferences, and, exhibitions (MICE) tourism hotel markets (Napierała, Leśniewska-Napierała, \& Burski, 2020). Moreover, the pandemic might enable a rethinking and reconceptualisation of relations between hotel enterprises and their competitors, identified in a much broader context than other hotels and accommodation facilities only. Affected by an unprecedented crisis of the hotel industry resulting from the COVID-19 pandemic, we are all witnessing a new wave of Schumpeterian 'creative destruction'. The evolutionary approach tells us to look to an extremely uncertain future of competition in the hotel industry from the perspective of the present, evidenced in this special issue. The recovery of the hotel industry in the future seems to be expected in both sustainability and innovation.

\section{References}

[1] Balli, E., Sigeze, C., Manga, M., Sahilli Birdir, S., \& Birdir, K. (2018). The relationship between tourism, CO2 emissions and economic growth: a case of Mediterranean countries. Asia Pacific Journal of Tourism Research, 24(5), 1-14. https://doi. org/10.1080/10941665.2018.1557717

[2] Bik, J., Poreda, A., \& Matczak, A. (2020). Conference facilities as a key factor in the competitiveness of urban hotels: $A$ case study of Łódź (Poland). European Journal of Tourism, Hospitality and Recreation, 10(3), 229-240. https://doi. org/10.2478/ejthr-2020-0020

[3] Boschma, R. A., \& Frenken, K. (2006). Why is Economic Geography not an Evolutionary Science? Towards an Evolutionary Economic Geography. Journal of Economic Geography, 6(3), 273-302.

[4] Brouder, P., \& Eriksson, R. H. (2012). Staying Power: What Influences Micro-firm Survival in Tourism? Tourism Geographies, 15(1), 125-144. https://doi.org/10.1080/14616 688.2011.647326

[5] Buhalis, D., \& Licata, M. C. (2002). The Future eTourism Intermediaries. Tourism Management, 23(3), 207-220.

[6] Czernek, K., \& Czakon, W. (2016). Trust-building processes in tourist coopetition: The case of a Polish region. Tourism Management, 52, 380-394. https://doi.org/10.1016/j. tourman.2015.07.009

[7] Dökmeci, V., \& Balta, N. (1999). The Evolution and Distribution of Hotels in Istanbul. European Planning Studies, 7(1), 99-109. https://doi.org/10.1080/09654319908720504

[8] Dwomoh, E., \& Moses, M. O. (2020). Job-Related Activity Patterns, Health Status, and Absenteeism Related Factors of Star-Rated Hotels Staff. European Journal of Tourism, Hospitality and Recreation, 10(3), 274-285. https://doi. org/10.2478/ejthr-2020-0024

[9] Giousmpasoglou, C., \& Thuy Hua, T. (2020). The Use of Self-Service Technologies in Budget Hotels: The Case of Bournemouth. European Journal of Tourism, Hospitality and Recreation, 10(3), 251-261. https://doi.org/10.2478/ ejthr-2020-0022

[10] Hjalager, A.-M. (2010). A review of innovation research in tourism. Tourism Management, 31(1), 1-12. https://doi. org/10.1016/j.tourman.2009.08.012

[11] Hunt, S. D. (2000). A General Theory of Competition: Resources, Competences, Productivity, Economic Growth. Thousand Oaks - London - New Delhi: Sage Publications Inc. 
[12] Napierała, T., Bahar, M., Leśniewska-Napierała, K., \& Topsakal, Y. (2020). Technology towards hotel competitiveness: Case of Antalya, Turkey. European Journal of Tourism, Hospitality and Recreation, 10(3), 262-273. https:// doi.org/10.2478/ejthr-2020-0023

[13] Napierała, T., Leśniewska-Napierała, K., \& Burski, R. (2020). Impact of Geographic Distribution of COVID-19 Cases on Hotels' Performances: Case of Polish Cities. Sustainability, 12(4697), 1-18. https://doi.org/10.3390/su12114697

[14] Napierala, T., \& Szutowski, D. (2019). The impact of localized innovations on the stock returns of tourism companies. International Journal of Tourism Research, 21, 108-121. https://doi.org/10.1002/jtr.2245

[15] Oxenswärdh, A. (2020). Sustainability Practice at Hotels on the Island of Gotland in Sweden - an exploratory study. European Journal of Tourism, Hospitality and Recreation, 10(3), 203-212. https://doi.org/10.2478/ejthr-2020-0018
[16] Parzych, K., \& Brkić-Vejmelka, J. (2020). Guests' assessment of hotel facilities and services: Zadar case study. European Journal of Tourism, Hospitality and Recreation, 10(3), 241-250. https://doi.org/10.2478/ejthr-2020-0021

[17] Penrose, E. (2011). The Theory of the Growth of the Firm. Oxford: Oxford University Press.

[18] Rumelt, R. P. (1997). Towards a Strategic Theory of the Firm. In N. J. Foss (Ed.), Resources, Firms, and Strategies: A Reader in the Resource-based Perspective (pp. 131-145). Oxford: Oxford University Press.

[19] Schumpeter, J. A. (1939). Business Cycles: A Theoretical, Historical, and Statistical Analysis of the Capitalist Process. New York - Toronto - London: McGraw-Hill Book Company.

[20] Ulucan, E. (2020). The Hotel Site Selection: Determining Locational Factors by Fuzzy TOPSIS. European Journal of Tourism, Hospitality and Recreation, 10(3), 213-228. https:// doi.org/10.2478/ejthr-2020-0019 